Diskursus: Jurnal Pendidikan Bahasa Indonesia

Vol. 3, No. 3, Desember 2020, pp. 268-273

p-ISSN: 2615-4935

e-ISSN: 2615-4943

\title{
Analisis Perbandingan Unsur Intrinsik Novel Dilan 1990 dan Film "Dilan 1990"
}

\author{
Suhirno ${ }^{1)}$ \\ Universitas Indraprasta PGRI \\ Jalan Nangka No. 58 C/TB. Simatupang, Tanjung Barat, Jakarta Selatan 12530 \\ E. Zaenal Arifin'2) \\ Universitas Indraprasta PGRI \\ Jalan Nangka No. 58 C/TB. Simatupang, Tanjung Barat, Jakarta Selatan 12530 \\ Restoeningroem $^{3)}$ \\ Universitas Indraprasta PGRI \\ Jalan Nangka No. 58 C/TB. Simatupang, Tanjung Barat, Jakarta Selatan 12530 \\ suhirnowabi67@gmail.com ${ }^{1)}$,zaenalarifin_48@yahoo.com ${ }^{2)}$
}

\begin{abstract}
This study aims to determine and describe the intrinsic elements of the Dilan 1990 novel by Pidi Baiq and to find out and describe the comparison of the results of the ecranization of the intrinsic elements of the Dilan 1990 novel in the "Dilan 1990" film by looking at aspects that are considered in the process of ecranization such as shrinking, adding and varying changes. This study used descriptive qualitative method. The data source of this research is the Dilan 1990 novel and the Dilan 1990 film. The focus of this study is on intrinsic elements and comparison of results of theme expansions, plot, characters, setting and language style. The research instrument uses a comparison table. The results of this study indicate that the comparison of the results of the ecranization of the intrinsic elements of novels and films in Dilan 1990. For the category of the aspect of shrinking as much as 26 were eliminated, the category of adding as much as 9 and the changes in the path as much as 8 changes.
\end{abstract}

Keywords: Comparative, Intrinsic Elements, Novels, Films

\begin{abstract}
Abstrak
Penelitian ini bertujuan untuk mengetahui dan mendeskripsikan unsur intrinsik dari novel Dilan 1990 karya Pidi Baiq dan untuk mengetahui dan mendeskripsikan perbandingan hasil unsur intrinsik novel Dilan 1990 pada film "Dilan 1990: dengan melihat aspek yang diperhatikan dalam proses ekranisasi seperti penciutan, penambahan dan perubahan bervareasi. Penelitian ini menggunakan metode deskriptif kualitatif. Sumber data penelitian ini ialah novel Dilan 1990 dan film "Dilan 1990". Fokus penelitian ini pada unsur intrinsik dan perbandingan hasil ekranisasi tema, alur, tokoh, latar dan gaya bahasa. Instrument penelitian menggunakan tabel perbandingan Hasil penelitian ini menunjukan bahwa perbandingan hasil ekranisasi unsur intrinsik novel dan film "Dilan 1990". Untuk kategori aspek penciutan alur sebanyak 26 yang dihilangkan, kategori penambahan alur sebanyak 9 dan perubahan pada alur sebanyak 8 perubahan.
\end{abstract}

Kata Kunci: Perbandingan, Unsur Intrinsik, Novel, Film 


\section{PENDAHULUAN}

Sastra adalah segala bentuk tulisan manusia. Sastra dalam pandangan khusus adalah segala ekspresi dan perasaan manusia dalam mengungkapkan gagasannya melalui bahasa yang lahir dari perasaan seseorang. Surastisna (2018:3) membagi sastra menjadi dua yaitu, prosa dan puisi. Perbedaan antara keduanya hanya tentang kaidah dan konteks penulisan. Jika dilihat dari tujuan keduanya sama-sama menyampaikan ide, gagasan, ekspresi, perasaan dan imajinasi seseorang. Akan tetapi prosa merupakan bentuk sastra yang tidak terikat aturan dan kaidah penulisannya berbeda dengan puisi yang terikat dengan kaidah dan aturan tertentu dalam penulisannya, contohnya syair dan pantun. Sedangkan contoh dari prosa adalah novel dan cerpen.

Menurut Teeuw (1984: 32) sastra tidak identik dengan bahasa tulis. Dari perbandingan antara bahasa lisan dan bahasa tulis kemudian dari survei tentang konsekuensi ciri khas bahasa tulis, jelaslah bahwa ketertulisan sastra mempunyai berbagai akibat, keadaan, potensi dan interpretasi sastra saat itu. Tetapi yang lebih penting lagi ialah bahwa sastra bukanlah soal tulisan, namun sastra berkenaan tentang isi, makna, rasa dan perasaan. Ketika novel bisa dikatakan dengan sastra bagaimana dengan nyanyian, drama tanpa naskah dan adegan dalam film, yang tujuannya sama seperti novel, menyampaikan pesan, kesan, maksud dan memuat ekspresi serta gagasan-gagasan pengarangnya.

Novel dan film adalah sebuah karya fiksi yang sering dijadikan subjek dalam proses adaptasi. Film juga dinilai sebagai media yang paling efektif dalam menyampaikan pesan. Hal ini dikarenakan, terdapat berbagai unsur yang terlibat di dalamnya seperti suara, visual, pemeranan, tata artistik, sastra dan penulisan skenario. Cerita yang diangkat oleh sebuah film seringkali merupakan bentuk adaptasi dari cerita dalam novel. Bentuk adaptasi atau alih media yang sering disebut dengan Ekranisasi di Indonesia telah berlangsung sejak lama. Salah satu film Indonesia yang dihasilkan dari proses Ekranisasi adalah Dilan 1990 yang diadaptasi dari novel Dia Adalah Dilanku Tahun 1990 karya Pidi Baiq dengan sutradara Fajar Bustomi.

Pemilihan film Dilan 1990 sebagai objek penelitian didasarkan beberapa alasan lain. Pertama, respon masyarakat yang begitu antusias terhadap film Dilan Dilanku 1990 karya Fajar Bustomi yang menjadikan novel Dilan ini best seller, bahkan ada beberapa media massa menyebutkan novel Dilan, Dilanku 1990 terjual 450 pcs dalam satu minggu. Banyak juga media massa yang menjadikan novel ini salah satu pembahasan di kolom utama, selain itu juga banyak para penulis yg menuliskan respon serta ulasannya di blog pribadi mereka. Kedua, Novel Dilanku 1990 karya Pidi Baiq telah di Filmkan dan disutradai oleh Fajar Bustomi dan Pidi Baiq. Film Dilan 1990 yang selama penayangannya menempati posisi teratas film terlaris sepanjang 2018 dengan jumlah penonton yang begitu fantastis sebanyak 6.315.664 orang, menjadikan salah satu film yang memiliki penonton terbanyak dalam sejarah perfilman Indonesia.

Film Dilan 1990 dibuat dari adaptasi novel karya Pidi Baiq. Film ini berawal dari suara Milea yang menceritakan masalalunya ditahun 1990 saat bertemu dengan Dilan di sebuah SMA di Bandung. Berawal dari perkenalan yang 
tidak biasa membawa Milea mengenal keunikan Dilan lebih jauh. Cerita milea faktanya mampu membawa film Dilan 1990 menempati posisi kedua penonton terbanyak setelah posisi pertama Warkop DKI Reborn part 1 berdasarkan data dari Filmindonesia.or.id.

Data dan fakta menarik di atas mampu membawa penulis dalam kegelisahan bagaimana mungkin novel Dilan 1990 menjadi senada dengan film Dilan 1990. Beberapa alasan tersebut yang membuat penulis tertarik untuk melakukan penelitian lebih lanjut mengenai proses alih media.

\section{METODE}

Metode yang digunakan dalam penelitian ini ialah metode deskriptif kualitatif. Penulis berusaha mendeskripsikan dan merekontruksi teori dari hasil pengamatan atau data-data yang telah terkumpulkan. Penelitian kualitatif merupakan prosedur penelitian yang menghasilkan data deskriptif berupa katakata tertulis atau lisan dari orang- orang dan perilaku yang diamati (Bogdan dan Taylor dalam Moleong, 2004:3).

Prosedur penelitian yang digunakan yaitu: 1) Membaca novel Dilan 1990 karya Pidi Baiq; 2) Menonton Film Dilan 1990 karya Fajar Bustomi; 3) Menyusun hipotesis atau gambaran umum setelah membaca dan menonton film Dilan 1990; 4) Mengumpulkan data dan menganalisis data; 5) Menarik simpulan; 6) Menguji keabsahan data

\section{HASIL DAN PEMBAHASAN}

Dilan 1990 dan Dilan 1991 merupakan film Indonesia yang terbilang sukses. Film remaja ini menceriterakan tentang kisah cinta anak sebuah SMA di Bandung, yakni Milea (diperankan oleh Vanessa Priscillia) dan Dilan (diperankan oleh Iqbaal Ramadhan). Cerita ini ditulis oleh penulis Pidi Baiq dengan setting kota Bandung tahun 90-an. Romantika kisah asmara dua remaja ini menjadi setting utama film ini. Gejolak kaum muda pun ditunjukan dengan adegan tawuran antar geng, bahkan ada adegan kekerasan terhadap guru di sekolah oleh tokoh Dilan. Film ini disutradarai oleh Fajar Bustomi dan Pidi Baiq sekaligus penulis naskah film ini. (Abdullah \& Permana, 2020: 86).

Adaptasi novel ke film adalah cara lain untuk menikmati karya fiksi. Novel merupakan sebuah karya sastra yang dinikmati dengan cara membaca, sedangkan film dinikmati dengan menontonnya. Novel dan film adalah karya fiksi yang banyak diadaptasi dari sebuah novel Perfilman Indonesia. Film dapat dinikmati dengan jangka waktu yang terbatas sehingga mendorong perpindahan dari novel ke layar lebar (film) dan membuat pembaca novel dapat menikmatinya dalam bentuk yang berbeda. Adaptasi novel ke film sebagai modifikasi dari narasi produktif, bentuk lain sebuah karya yang berupa tulisan menjadi cerita yang bergambar dan ditampilkan di bioskop atau layar televise (Woodrich dalam Widhayani, Suwandi, \& Winarni, 2018: 188-189). 
Berikut ini hasil temuan penelitian tentang perbandingan hasil ekranisasi unsur intrinsik pada novel dan film Dilan 1990 Karya Pidi Baiq dan Fazar Bustomi sebagai sutradara.

1. Unsur intrinsik pada novel Dilan 1990 memiliki tema percintaan dan persahabatan. Novel ini juga menggunakan alur mundur. Secara umum berlatar tempat kejadian di Bandung, dengan suasana Bandung yang khas dengan kesejukan. Novel ini menceritakan kisah pada tahun 1990, sehingga suasana Bandung masih belum ramai. Novel ini menceritakan kisah Dilan dan Milea. Sehingga keduanya menjadi tokoh utama dalam Novel mau pun film. Penceritaan Pidi Baiq sebaga penulis novel Dilan 1990 menggunakan gaya bahasa baku, sederhana namun penuh dengan filosofi.

2. Selain alur dalam novel, selanjutnya latar mengalami ekranisasi sebanyak 13 dengan klasifikasi, aspek penciutan 8, penambahan 1 dan perubahan latar sebanyak 4 kali. Penciutan latar dilakukan karena mengikuti alur sama halnya dengan penambahan. Ketika alur ditambahkan maka bertambahlah latar pada film. Adapun perubahan juga masih wajar dilakukan karena mengingat terlalu banyaknya scene dalam film jika mengikuti novel. Ekranisasi pada tokoh dalam penelitian ini ditemukan sebanyak 11 kali dengan penghilangan 8 tokoh, 1 tokoh ditambahkan dan 2 kali perubahan tokoh. Untuk gaya bahasa yang digunakan pada film hanya terletak pada penggunaan bahasa saat improvisasi oleh actor atau aktris film Dilan 1990

Sastra Indonesia sudah ada sejak abad ke 20 dan berkembang sampai saat ini. Pada saat itu sastra Indonesia baru berbentuk surat, buku, surat kabar dan majalah yang dahulu diterbitkan oleh penerbit pers baik dari usaha kalangan swasta maupun oleh pemerintah Kolonial Belanda. Jadi sastra Indonesia memang sudah ada sejak ratusan tahun yang lalu dibuktikan oleh ratusan novel, ribuan cerpen bahkan puisi-puisi yang tersebar di media cetak.

Selain itu juga telah tercatat dalam sejarah kesastraan Indonesia namanama tokoh pengarang yang sekaligus menjadi pakar sastra seperti Ajip Rosidi, Chairul Anwar, Taufik Ismail, Umar Kayam dan Mangunwijaya, yang kini menjadi tokoh inspirasi sastrawan Indonesia dan para pengarang muda. Hasil karya para tokoh juga tidak bisa diragukan, novel-novel yang melegendaris menjadi peninggalan yang selalu hidup seolah tak mati walau pun zaman sudah berganti, seperti Azab dan Sengsara, Belenggu, Di Bawah Lindungan Kabah, Nyai Dasima, Salah Asuhan dan Siti Nurbaya yang sampai saat ini menjadi bacaan pilihan.

Di Indonesia perkembangan sastra semakin pesat. Kegemaran generasi muda terhadap karya sastra mengakibatkan banyaknya hasil karya yang berceceran. Sebagai media untuk menuangkan perasaan, ide-ide dan emosi serta pengalaman, membuat eksistensi sastra banyak digemari oleh para generasi. Maka tak heran jika kini banyak penerbit yang menerbitkan novel-novel dari hasil ciptaan sastrawan muda bahkan dari berbagai kalang.

Pidi Baiq misalnya, beliau adalah seorang seniman muda penulis novel dan buku yang baru-baru ini mengagetkan dunia sastra dengan kemunculan Novel yang bergenre humor dan romansnya yang fenomenal. Karyanya yang berjudul Dilan; Dia Adalah Dilanku 1990 yang terbit tahun 2014. 
Kemunculan novel Dilan mampu membuat para remaja terbawa perasaan setelah membacanya dan ditahun 2014 novel Dilan menjadi buah bibir yang menarik untuk diceritakan. Kisah romansnya yang membuat para remaja meleleh dengan isi yang diceritakannya yaitu Dilan yang menjadi tokoh yang di idolakan para wanita. Gaya Dilan yang tangkas, jentel, koccak, humoris dan juga romantis yang sangat ditonjolkan dari novel tersebut membuat novel itu laris manis dan banyak digemari.

Popularitas novel Dilan 1990 pada tahun 2015 mampu mengangkat cerita novel ke layar lebar pada tahun 2018. Kerinduan penggemar Dilan terobati seketika. Penasaran dengan kemasan Dilan dalam fisik audiovisual cukup menarik perhatian publik.

Film Dilan yang diperankan oleh pemeran utama Iqbal Ramadhan dan Vanesha Prisila sebagai Dilan dan Milea membuat tak hanya penikmat novel Dilan yang menunggu tayangnya film tersebut. Namun para pens club Iqbal juga menunggu kehadiran film. Selain itu, film tersebut dipromosikan dengan trailer yang begitu unik dan menarik membuat para penonton penasaran dengan cerita sebenarnya, sehingga rasa penasaran mendorong para penonton untuk membaca novel sebelum film yang mereka tunggu tayang.

Setelah penanyangan film berbagai kontraversi muncul. Film yang kononnya diangkat dari kisah nyata namun banyak memuat alur yang imajinatif, perbedaan yang terjadi antara novel dan film seerta kekecewaan penggemar yang menyangkan ketika alur cerita harus dipangkas, mebuat Pidi Baiq dan Fajar Bustomi angkat bicara. Memang sangat disayangkan ketika harus ada bagian atau adegan yang dipotong namun tidak memungkin untuk dipaksakan satu buah novel penuh masuk kedalam sebuah film dengan durasi 120 menit tanpa pemangkasan, perubahan dan penambahan pada adegan.

\section{SIMPULAN}

Berdasarkan hasil dan pembahasan, dapat disimpulkan bahwa perbandingan hasil ekranisasi unsur intrinsik novel dan film "Dilan 1990" untuk kategori aspek penciutan alur sebanyak 26 yang dihilangkan, kategori penambahan alur sebanyak 9 dan perubahan pada alur sebanyak 8 perubahan.

\section{DAFTAR PUSTAKA}

Abdullah, A., \& Permana, R. S. M. (2020). Pembingkaian media mengenai "Sudut Dilan" yang terinspirasi Film Dilan 1990 dan 1991. ProTVF, 4(1), 85-104. http://jurnal.unpad.ac.id/protvf/article/view/24184

Baiq, P. (2015). Dilan 1990. Jakarta: Mizan Publishing.

Baiq, P., \& Wattimena, T. (2018). Film Dilan 1990. Jakarta: Max Pictures.

Moleong, L.J. (2004). Metode penelitian kualitatif. Bandung: PT. Remaja Rosdakarya.

Surastina. (2018). Pengantar teori sastra. Yogyakarta: Elmatera Yogyakarta 


\section{Diskursus: Jurnal Pendidikan Bahasa Indonesia}

Vol. 3, No. 3, Desember 2020, pp. 268-273

p-ISSN: 2615-4935

e-ISSN: 2615-4943

Teeuw, A. (1984). Sastra dan ilmu sastra. Bandung. Pustaka Jaya.

Widhayani, A., Suwandi, S., \& Winarni, R. (2018). Ecranisation study: From Novel to Film Dilan 1990. Humanus, 17(2), 188-201. http://ejournal.unp.ac.id/index.php/humanus/article/view/100389 